and evaluation; a decline in the specific privileges of the professoriate; an increase in the flexible and casual nature of the academic work force; and a decrease in the attractiveness of the academic career.

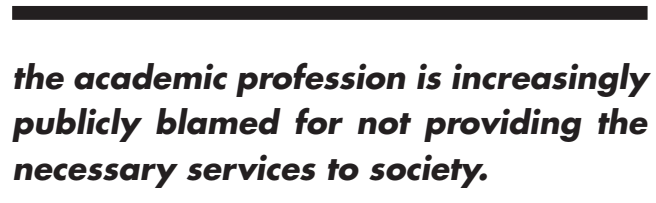

In summer 1998, the Center for Research on Higher Education and Work in Kassel, Germany, initiated a project called "The Employment and Working Conditions of Academic Staff in Higher Education: A Comparative Study in the European Community." The project's aim is to deepen our understanding of recent developments in this area, thus contributing to an international discussion in which widely held claims about the academic profession are not just taken for granted, but also tested. Experts from 15 countriesAustria, Belgium, Denmark, Finland, France, Germany, Greece, Ireland, Italy, the Netherlands, Norway, Portugal, Spain, Sweden and the United Kingdom-have been invited to write country reports highlighting developments over the last two decades and the state-of-the-art of the academic profession in the different national contexts. Publication of the first results in comparative perspective is expected in winter 1999 .

The study has three main objectives: first, to analyze major traditional features of the academic profession and its occupational ranking and career structure and to gather up-to-date information about the employment and working conditions of academic staff in the European countries involved. The data and analysis cover issues related to staff structure, academic appointment and employment arrangements, and academic careers. Second, the study analyzes the distribution of responsibility and power among the relevant actors and changes in the rules and regulations covering staffing in higher education. Third, the study is analyzing changes in the employment and working conditions of academic staff over the last several years and current debates on these issues: to what extent are various aspects of employment and working conditions an explicit or implicit target of reorganization? What are the underlying assumptions and aims? What are the perceived impacts of these developments on the positioning of the academic profession?

The preliminary results were discussed by the country experts and higher education policymakers in an international project conference held in April 1999 in Kassel. The study appears to have been a mostly timely one: many European countries are in the midst of reorganizing the actors and procedures in higher education and the rules and regulations covering employment relationships among academic staff. The study is, therefore, examining a moving target of growing concern for the future of higher education and its most important asset-the academic staff.

\section{The Question of Degrees in Canadian Higher Education}

\section{Paul Goyan and Glen A. Jones}

Paul Goyan is a doctoral student in the Higher Education Group of the Ontario Institute for Studies in Education of the University of Toronto (OISE/UT). Glen A. Jones is Associate Professor of Higher Education, OISE/UT, 252 Bloor Street West, Toronto, Ontario, Canada, M5S 1 V6.

$\mathrm{T}$ he Canadian higher education policy environment is highly decentralized, and yet scholars have noted that during the period from 1945 until the late 1960s, a common institutional form slowly evolved. Pushed by student demand and pulled by government funding policies that differed by province, Canadian universities gradually became defined as public, secular, comprehensive, high-access, degree-granting institutions. The Canadian universities' public monopoly over degree granting has been recently challenged by initiatives in the provinces of British Columbia and Alberta that extend limited degree-granting authority to institutions in the nonuniversity sector in order to improve accessibility and to increase the production of technical graduates.

Until recently, British Columbia had three universities: the University of British Columbia, established in 1915; and the University of Victoria and Simon Fraser University, established in the 1960s. During the 1960s, the province established a system of community colleges that provided vocational education as well as first- and second-year university transfer courses. The BC Council on Admissions and Transfers facilitates articulation between the community colleges and universities. The province also has an Open University and an Open College delivering vocational and degree-level programs as part of the $\mathrm{BC}$ Open Learning Agency. In the 1980s, BC became the first province to charter a private, sectarian university-Trinity Western—through a private member's bill in the legislature.

Although BC has a large community-college sector, youth participation in university education in the province has been among the lowest in Canada. As a result, the provincial government created a number of new institutions in the 1990s and made some changes to the mission of existing community colleges. The University of Northern British Columbia was established using the research 
university model, with a particular mandate to serve the large aboriginal population and support northern industrial development. Five of the 16 community colleges were renamed university-colleges and now grant baccalaureate degrees. For the remaining community colleges in BC, the province introduced the associate degree found in the United States. A small number of technical institutes have also been given limited authority to grant technical degrees - most notably the BC Institute of Technology, which is now offering Bachelor of Technology degrees.

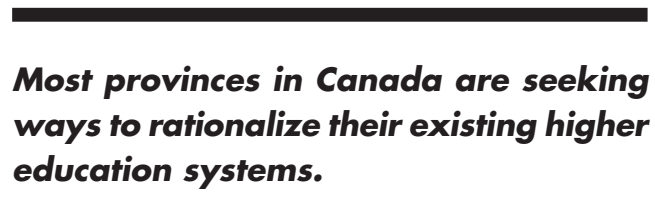

Royal Roads University was established in the early 1990s on the site of a former federal military college. Its mission is to deliver applied and professional programs to midcareer learners from across Canada and around the world, primarily on a cost-recoverable basis. Most recently, the government announced the establishment of the Technical University of British Columbia, which will train graduates required by industry and conduct applied research. TechU will not have an academic senate or grant faculty tenure. The Canadian Association of University Teachers has argued that TechU is not really a university and has called for a boycott by scholars. Together, these recent initiatives in BC are designed to increase accessibility to degree-level education within the province and enhance the production of graduates and applied research to respond to the province's economic and labor market requirements.

The government of Alberta has also introduced changes that alter the traditional binary nature of Canadian higher education. The Alberta changes must be considered within an overall context of significant budget reductions and increasing enrollments. Between 1994 and 1997, the province reduced operating grants to public higher education institutions by 21 percent. The province is now reinvesting some money in higher education through a number of new funding envelopes designed to improve access, support learning technologies, and to enhance infrastructure renewal and research.

In 1995, Alberta introduced a policy to approve applied degree programs at its 11 community colleges and 2 technical institutes. Like BC, Alberta's community colleges were initially established on the American junior college model and offer first- and second-year university transfer courses. Articulation arrangements are coordinated through the Alberta Council on Admissions and Transfers. The introduction of applied degrees recognizes the increasing technical complexity of technological programs.

In addition to its three traditional universities (Alberta, Calgary, and Lethbridge), Alberta established Athabasca University in the 1970s as Canada's first university wholly devoted to distance learning. In recent years, Athabasca has expanded its mandate to reach across Canada, the United States, and Mexico, and has worked aggressively to establish partnerships and articulation arrangements with other institutions.

In the early 1980s, Alberta established the Private Colleges Accreditation Board as a mechanism to oversee the accreditation of degree programs offered by private colleges in Alberta, primarily sectarian colleges. As part of the accreditation process, however, institutions were first required to establish an affiliation agreement with a public university. Generally, universities were reluctant to enter into such arrangements. Four private colleges have received degree-level accreditation for specific programs and have become private university-colleges operating without public funding. In 1998, the province revised the legislation to remove the affiliation requirement in order to accommodate a broader range of institutions and programs.

It is uncertain how much of an impact the initiatives in British Columbia and Alberta may have on government policymaking in other Canadian provinces in the coming years. It is already clear, however, that the extension of degree-granting authority to postsecondary nonuniversity institutions raises interesting questions for Canadian higher education. The relative homogeneity of the university sector, combined with assumptions that the quality of educational experience provided by these institutions was roughly comparable, meant that a national mechanism for institutional accreditation was unnecessary. It will be interesting to see how the graduates of these new institutions and degree programs will be treated by other Canadian universities when questions of transfer or graduate program admissions arise, or how these new degree-granting institutions will be viewed by the organizations and networks associated with the "traditional" universities.

Most provinces in Canada are seeking ways to rationalize their existing higher education systems. Despite numerous reports calling for increased diversity and differentiation, many provinces have to date been reluctant to make significant changes to the existing arrangements or institutional models. At the same time, private-sector calls for greater utility on the part of universities in supporting market needs, together with the increasing complexity of technological programs at community colleges, may result in governments introducing further changes to Canadian higher education systems in the decade ahead. Following the lead of British Columbia and Alberta, such changes may emphasize college-university articulation, extending degree-granting to the nonuniversity sector, and introducing technical or applied degrees. 